\title{
Возраст и генезис золото-серебряного месторождения Покровское (Дальний Восток России)
}

Сорокин А. А., Кадашникова А. Ю., Пономарчук А. В., Травин А. В., Пономарчук В. А.

\begin{abstract}
Аннотация
Приведены результаты геохронологических исследований пород различных магматических комплексов, а также рудных образований (гидротермально-измененных вулканических пород с промышленным Au-Ag оруденением), представленных в пределах месторождения Покровское. Показано, что возраст гранитов Сергеевского массива верхнеамурского комплекса, вмещающих рудные тела, составляет 129 млн лет. Первичный возраст дацитов силлообразного тела, может быть оценен в интервале 128-125 млн лет, что соответствует возрасту вулканических пород талданского комплекса. Возраст наложенных на эти дациты процессов пропилитизации, в первом приближении, может быть оценен интервалом 122-119 млн лет. Принимая во внимание присутствие в рассматриваемых породах промышленных концентраций золота и серебра, мы полагаем, что этот возрастной интервал может быть распространен и на процесс формирования рудных тел. В пределах Умлеканской вулканической зоны на рассматриваемый возрастной интервал (122-119 млн лет) приходится становление галькинского вулканического комплекса, сопровождаемого гранитоидным магматизмом того же возраста. На этом основании мы полагаем, что формирование месторождения Покровское, вероятно, связано с галькинским комплексом.
\end{abstract}

\section{Ключевые слова:}

Месторождение Покровское, Аргунский континентальный массив, Ar-Ar геохронология, мезозой, магматизм 


\title{
Возраст и генезис золото-серебряного месторождения Покровское (Дальний Восток России).
}

\author{
А.А. Сорокин ${ }^{1}$, А.Ю. Кадашникова ${ }^{1}$, А.В. Пономарчук ${ }^{2}$, А.В. Травин ${ }^{2,3}$, \\ В.А. Пономарчук ${ }^{2}$ \\ ${ }^{1}$ Институт геологии и природопользования ДВО РАН, 675000, Благовещенск, \\ пер. Рёлочный, д. 1, Россия \\ ${ }^{2}$ Институт геологии и минералогии СО РАН, 630090, Новосибирск, \\ пр. Ак. Коптюга, д. 3, Россия \\ ${ }^{3}$ Национальный исследовательский Томский государственный университет, \\ 634050, Томск, пр. Ленина, д. 36, Россия
}

Приведены результаты геохронологических исследований пород различных магматических комплексов, а также рудных образований (гидротермально-измененных вулканических пород с промышленным Au-Ag оруденением), представленных в пределах месторождения Покровское. Показано, что возраст гранитов Сергеевского массива верхнеамурского комплекса, вмещающих рудные тела, составляет 129 млн лет. Первичный возраст дацитов силлообразного тела, может быть оценен в интервале 128-125 млн лет, что соответствует возрасту вулканических пород талданского комплекса. Возраст наложенных на эти дациты процессов пропилитизации, в первом приближении, может быть оценен интервалом 122-119 млн лет. Принимая во внимание присутствие в рассматриваемых породах промышленных концентраций золота и серебра, мы полагаем, что этот возрастной интервал может быть распространен и на процесс формирования рудных тел. В пределах Умлеканской вулканической зоны на рассматриваемый возрастной интервал (122-119 млн лет) приходится становление галькинского вулканического комплекса, сопровождаемого гранитоидным магматизмом того же возраста. На этом основании мы полагаем, что формирование месторождения Покровское, вероятно, связано с галькинским комплексом.

Ключевые слова: Месторождение Покровское, Аргунский континентальный массив, Ar-Ar геохронология, мезозой, магматизм

\section{ВВЕДЕНИЕ}

Северо-восточная окраина Аргунского континентального массива, обращенная в

Рис. 1 сторону Монголо-Охотского складчатого пояса, является ареной широкомасштабного проявления мезозойского магматизма (рис. 1). Здесь же представлены многочисленные и разнообразные по своему составу месторождения и рудопроявления цветных, редких и благородных металлов (Покровское (Au-Ag), Пионер (Au), Буринда (Au-Ag), Боргуликан (Cu-Mo-порфировое с $\mathrm{Au}$ ), Икан (Cu-Mo-порфировое с $\mathrm{Au})$, Верхнетыгдинское (Cu-Moпорфировое с $\mathrm{Au})$, Елна (Cu-порфировое с $\mathrm{Au})$, Двойное (Cu-порфировое с $\mathrm{Au})$, Ельничное

Рис. 2 (Сu-порфировое с Аu) и др.) (рис. 2). При этом главной эпохой рудообразования в пределах рассматриваемого региона является позднемезозойская (см. обзор в [Эйриш, 2002; Геодинамика..., 2006]). 
В последние годы для целого ряда "реперных" рудных объектов рассматриваемого региона выполнены геохронологические исследования, позволяющие с большой надежностью связывать процессы рудообразования с конкретными магматическими комплексами и тектоническими событиями [Сотников и др., 2005, 2007а; Бучко и др., 2017, 2018; Ефремов и др., 2019]. Результаты таких исследований представляют необходимый базис для металлогенических построений нового поколения, однако таких данных явно недостаточно для разработки общей концепции формирования рудных месторождений, связанных с мезозойскими процессами.

Единственным путем решения этой проблемы являются комплексные геологоструктурные, геохронологические исследования типовых месторождений данного региона. К таким объектам, безусловно, относится золото-серебряное Покровское месторождение, которое и является объектом данного исследования. Это месторождение расположено в северо-восточной части Аргунского континентального массива (восточная часть Центрально-Азиатского складчатого пояса) на правобережье р. Зея (бассейн р. Амур) (рис. 1,2,3) и относится к числу наиболее известных в Приамурье.

Целью данной работы является установить возраст магматических пород, а также рудных образований (гидротермально-измененных вулканических пород с промышленным Au-Ag оруденением), представленных в пределах месторождения. На основании полученных данных будет намечена связь рудного процесса с тем или иным магматическим комплексом.

\section{ГЕОЛОГИЧЕСКАЯ ПОЗИЦИЯ МЕСТОРОЖДЕНИЯ ПОКРОВСКОЕ}

Как было отмечено выше, Покровское месторождение расположено в северовосточной части Аргунского континентального массива.

Согласно традиционным представлениям, фундамент Аргунского континентального массива сложен раннедокембрийскими метаморфическим комплексами [Решения..., 1994; Геодинамика..., 2006; Петрук, Козлов, 2009 и др.,]. Вместе с тем полученные за последние годы геохронологические и изотопно-геохимические данные свидетельствуют о том, что наиболее древние породы в строении рассматриваемого массива имеют возраст не древнее неопротерозоя [Котов и др., 2009, 2013; Сальникова и др., 2012; Гордиенко и др., 2019; Wu et al., 2011; Wu et al., 2012; Miao et al., 2015 и др.].

На ранний палеозой (кембрий, ордовик) в геологической истории Аргунского континентального массива приходится этап интенсивного проявления интрузивного преимущественно кислого магматизма и вулканизма [Сорокин и др., 2004a, 2014б; Wu et al., 2011 и др.]. Значительную роль в строении рассматриваемого массива играют терригенные и терригенно-карбонатные отложения, охватывающие стратиграфический интервал от силура до нижнего карбона [Геодинамика..., 2006; Петрук Козлов, 2009]. Позднепалеозойский магматизм представлен интрузиями габбро-диорит-гранодиоритгранитного состава, приуроченными к северной окраине Аргунского континентального массива, обращенной в сторону Монголо-Охотского складчатого пояса [Мартынюк и др., 1990; Сорокин и др., 2005; Петрук Козлов, 2009].

$\mathrm{K}$ наиболее молодым образованиям относятся деформированные позднетриасовые(?)-юрские осадочные отложения Верхнеамурского прогиба, позднемезозойские вулканические и вулкано-плутонические комплексы, а также кайнозойские рыхлые отложения Амуро-Зейской впадины. 
Большинство рудных объектов северо-восточной части Аргунского континентального массива связаны именно с Умлекано-Огоджинским поясом (см. обзор в [Эйриш, 2002; Хомич, Борискина, 2003, 2006; Геодинамика..., 2006 и др.]). По существующим представлениям [Мартынюк и др., 1990; Геологическая..., 1999; Парфенов и др., 2003; Геодинамика..., 2006 и др.] этот пояс в виде цепочки вулканических полей и интрузивных тел прослеживается в субширотном направлении более чем на 500 км вдоль границы с Монголо-Охотским складчатым поясом.

В пределах Умлекано-Огоджинского пояса выделяется до 20 вулканических структур, объединяемых в Умлеканскую (западную) и Огоджинскую (восточную) вулканические зоны [Мартынюк и др., 1990; Геодинамика..., 2006 и др.]. Согласно этой схеме районирования месторождение Покровское находится в пределах Улунгинской вулкано-тектонической структуры [Хомич, Борискина, 2003] Умлеканской вулканической зоны. В металлогеническом плане оно расположено в пределах Улунгинского медносеребро-золоторудного узла в составе Умлекано-Огоджинской молибденово-медносеребро-золоторудной минерагенической зоны [Сережников, Волкова, 2005] (рис. 1).

\section{ГЕОЛОГИЧЕСКОЕ СТРОЕНИЕ МЕСТОРОЖДЕНИЯ ПОКРОВСКОЕ}

Структурная позиция, строение, минеральный состав руд месторождения Покровское неоднократно описаны в литературе [Эйриш, 2002; Хомич, Борискина, 2003, 2006; Золоторудные..., 2010; Пересторонин, Степанов, 2016 и др.]. В этой связи ниже мы приводим лишь краткую информацию, имеющую отношение к проблеме связи оруденения и магматизма.

В пределах Покровского рудного поля наиболее древние образования представлены верхнеюрскими песчаниками, алевролитами, аргиллитами осежинской [Зубков, Вольский, 1984] свиты. Они смяты в брахиформные складки и прорваны биотитовым гранитами и гранодиоритами раннемелового верхнеамурского комплекса (Сергеевский массив).

Улунгинская вулкано-тектоническая структура сложена раннемеловыми вулканитами андезитами, дацитами, их туфами, кластолавами талданской свиты и базальтами, риолитами, туфами, туфобрекчиями, туфопесчаниками галькинской свиты. Субвулканические фации вулканитов талданской свиты слагают многочисленные силлы и дайки дацитов, диоритовых порфиритов. Широко развиты также дайки гранит-порфиров, гранодиорит-порфиров. Это палеовулканическое сооружение является (по [Эйриш, 2002; Хомич, Борискина, 2003, 2006; Золоторудные..., 2010]) стержневым элементом структуры Покровского рудного поля. Основные рудоносные участки расположены среди гранитоидов Сергеевского массива и эффузивно-пирокластических образований вблизи от выводного канала палеовулкана (палеожерловины, по [Хомич, Борискина, 2003]) Рис. 4 (рис. 3, 4).

По характеру геологического строения и степени рудоносности в пределах рудного поля выделены три участка: Покровка-1, Покровка-2 и Покровка-3 (рис. 3, 4). Рудные тела, вмещающие основные запасы золота (Главное, Новое, Озерное, Зейское и Молодежное), расположены в западной части месторождения на участках Покровка-1 и Покровка-3. Они локализованы в гранитоидах или приурочены к контакту гранитов и перекрывающих их вулканитов, а также в вулканитах [Золоторудные..., 2010, Пересторонин, Степанов, 2016]. Содержание золота в рудных телах обычно не превышает 1-3 г/т. По совокупности геологических и минералогических признаков месторождение Покровское относится к золотосеребряной формации [Эйриш, 2002; Золоторудные..., 2010]. 
Непосредственными объектами наших исследований были магматические породы различных комплексов, а также рудные образования, представленные на участке Покровка-1. Оруденение на этом участке сосредоточено, преимущественно, в гранитах (рис. 4). Рудная залежь ограничена сверху надрудной толщей метасоматически преобразованных вулканитов и снизу дайковым телом силлобразной формы дацитовгранодиорит-порфиров ("силлом" по [Хомич, Борискина, 2003, 2006; Геодинамика..., 2006; Золоторудные..., 2010, Пересторонин, Степанов, 2016]).

Для геохронологических исследований нами были использованы следующие образцы:

1) Граниты (обр. АМ-3, АМ-13) Сергеевского массива, вмещающие рудные тела "Озерное" и "Зейское". Эти породы в обоих случаях претерпели в незначительной степени окварцевание, аргиллизацию. Последняя выражается в замещении плагиоклазов глинистыми минералами, гидрослюдой, развитию по темноцветным минералам хлорита, сульфидов, гематита. При этом калиевый полевой шпат остается относительно устойчивым к этим преобразованиям.

2) Дациты (обр. AM-4, AM-15) верхней части дайкового тела силлобразной формы ("силла"), снизу ограничивающего рудные тела "Озерное" и "Главное". Породы в значительной степени пропилитизированы, окварцованы, аргиллизированы. Минералогически это проявлено в хлоритизации биотита, замещении плагиоклазов глинистыми минералами, развитию хлорита, гидрослюд по основной массе. Эти вторичные преобразования, по нашему мнению, относятся непосредственно к рудному процессу, поскольку в данные образцы характеризуются промышленными концентрациями Au (0.7-0.8 г/т), Ag (5-12 г/т).

Места отбора образцов показаны на рисунках 3, 4.

\section{АНАЛИТИЧЕСКИЕ МЕТОДИКИ}

${ }^{40} \mathrm{Ar} /{ }^{39} \mathrm{Ar}$ изотопно-геохронологические исследования выполнены в Институте геологии и минералогии СО РАН (г. Новосибирск) методом ступенчатого прогрева по методике, опубликованной в работах [Пономарчук и др., 1998; Травин и др., 2009]. Отбор материала проводился вручную под бинокулярной лупой из фракции 0.25-0.15 мм. Навески образцов, совместно с мусковитом МСА-11, используемым в качестве монитора, заворачивались в алюминиевую фольгу, помещались в кварцевую ампулу и после откачки из нее воздуха запаивались. Мусковит МСА-11, подготовленный в ВИМС в 1988 году как стандартный K/Ar-образец, был аттестован в качестве ${ }^{40} \mathrm{Ar} /{ }^{39} \mathrm{Ar}-$ монитора с помощью международных стандартных образцов мусковита Bern 4m, биотита LP-6 [Baksi, 1996]. B качестве интегрального возраста мусковита МСA-11 принято среднее результатов калибровки, составившее $311.0 \pm 1.5$ млн лет. Ампулы с образцами помещались в алюминиевый пенал, заполненный для защиты от тепловых нейтронов карбидом бора, и облучались в охлаждаемом водой канале научного реактора ВВР-К-типа (исследования проводились в Физико-техническом институте при Томском политехническом университете). Градиент нейтронного потока не превышал $0.5 \%$ в размере образца. Эксперименты по ступенчатому прогреву проводились в кварцевом реакторе с печью внешнего прогрева. Холостой опыт по определению ${ }^{40} \mathrm{Ar}\left(10\right.$ мин при $\left.1200^{\circ} \mathrm{C}\right)$ не превышал $5 \times 10^{-10}$ нсм $^{3}$. Очистка аргона производилась с помощью ZrAl-SAES-геттеров. Изотопный состав аргона измерялся на масс-спектрометре Noble gas 5400 фирмы 
MicroMass (Англия). Для коррекции на мешающие изотопы аргона, образовавшиеся во время облучения на $\mathrm{Ca}, \mathrm{Cl}, \mathrm{K}$, использовались следующие коэффициенты: $\left({ }^{39} \mathrm{Ar} /{ }^{37} \mathrm{Ar}\right)_{\mathrm{Ca}}=0.00083 \pm 0.000005,\left({ }^{36} \mathrm{Ar} /{ }^{37} \mathrm{Ar}\right)_{\mathrm{Ca}}=0.00052 \pm 0.000006,\left({ }^{40} \mathrm{Ar} /{ }^{39} \mathrm{Ar}\right)_{\mathrm{K}}=0.089 \pm$ 0.001. Особое внимание уделялось контролю фактора изотопной дискриминации с помощью измерения порции очищенного атмосферного аргона. Среднее значение отношения ${ }^{40} \mathrm{Ar} /{ }^{36} \mathrm{Ar}$ на период измерений составило $296.8 \pm 0.5$. Величины температур ступенчатого прогрева выбирались согласно [Berger, York, 1981]. В случае согласованных значений возраста, полученных при расчете по плато и в изохронном варианте, нами принималось значение с меньшей погрешностью. При интерпретации полученных данных использованы критерии, предложенные в работах [Fleck et al., 1977; Gustafson et al., 2001].

\section{РЕЗУЛЬТАТЫ ГЕОХРОНОЛОГИЧЕСКИХ ИССЛЕДОВАНИЙ}

Табл.

Рис. 5

Результаты проведенных исследований приведены в таблице и на рисунке 5 и сводятся к нижеследующему.

Возраст полевого шпата из аргиллизированных окварцованных гранитов Сергеевского массива (обр. АМ-3), вмещающих рудное тела "Озерное", при расчете по плато составил $126 \pm 3$ млн лет (90\% выделенного ${ }^{39} \mathrm{Ar}$ ) (табл., рис. 5а), в изохронном варианте $-122 \pm 6$ млн лет, СКВО=0.88 (рис. 5б).

Возраст биотита из пропилитизированных дацитов (обр. АM-4) дайкового тела силлобразной формы, постилающего рудное тело "Озерное", при расчете по плато составил $125 \pm 2$ млн лет (94\% выделенного ${ }^{39} \mathrm{Ar}$ ) (табл., рис. 5в), возраст основной массы (хлорит-гидрослюдистого агрегата) $122 \pm 1$ млн лет (83\% выделенного ${ }^{39} \mathrm{Ar}$ ), (табл., рис. 5д). Близкие значения возрастов, но с большей погрешностью, получены и в изохронном варианте расчета: $123 \pm 2$ млн лет, СКВО=1.8 (рис. 5г) и $123 \pm 2$ млн лет, $\mathrm{CKBO}=2.1$ (рис. 5e).

Возраст биотита из аргиллизированных окварцованных гранитов Сергеевского массива (обр. АМ-13), вмещающих рудное тело "Зейское", при расчете по плато составил $124 \pm 5$ млн лет (70 \% выделенного ${ }^{39} \mathrm{Ar}$ ) (табл., рис. 5ж), в изохронном варианте $-119 \pm 6$ млн лет, $\mathrm{CKBO}=0.65$ (рис. 53). При этом следует отметить и отчетливую ступень с возрастом 115 млн лет (25\% выделенного $\left.{ }^{39} \mathrm{Ar}\right)$. Возраст полевого шпата из этого же образца оценивается нами по "псевдоплато", образованному 5-6 ступенями (69\% выделенного $\left.{ }^{39} \mathrm{Ar}\right)$, которое соответствует $129 \pm 6$ млн лет, (табл., рис. 5и).

Аргонограмма для основной массы из пропилитизированных дацитов (обр. АM-15), дайкового тела силлобразной формы, постилающего рудное тело "Главное", не позволяет выделить плато (табл., рис. 5к). Тем не менее на ней отчетливо выражены ступени с возрастом $\sim 128$ млн лет, $\sim 125$ млн лет, $\sim 120$ млн лет и $\sim 119$ млн лет.

\section{ОБСУЖДЕНИЕ РЕЗУЛЬТАТОВ}

Полученные данные позволяют оценить возраст магматических пород, а также рудных образований (гидротермально-измененных вулканических пород с промышленным Au-Ag оруденением), представленных в пределах Покровского месторождения

Прежде чем обсуждать проблему связи формирования рассматриваемого месторождения с тем или иным магматическим комплексом, напомним, что в истории формирования Умлеканской вулканической зоны выделяется следующая последовательность магматизма: верхнеамурский и буриндинский гранитоидные комплексы - 140-127 млн лет; талданский андезит-дацитовый комплекс - 127-123 млн лет; 
галькинский бимодальный комплекс - 119-115 млн лет; трахиандезитовый комплекс - 10594 млн лет [Сорокин и др., 2004б, 2009, 2010, 2013; Сотников и др., 2007а].

Далее обратимся к геохронологическим данным, полученным в ходе настоящего исследования.

С учетом вторичных преобразований минимальный возраст гранитов Сергеевского массива верхнеамурского комплекса может быть оценен по возрасту биотита из образцов AM-3 (126 \pm 3 млн лет, рис. 5а) и АМ-13 (124 \pm 5 млн лет, рис. 5ж), а также возраста калиевого полевого шпата из образца АМ-13 (129 \pm 6 млн лет, рис. 5и). При этом наиболее древний возраст получен для калиевого полевого шпата - одному из наиболее устойчивых минералов в процессе аргиллизации [Волостных, 1972]. Таким образом, по нашим данным, возраст рассматриваемых пород составляет 129 млн лет. Эти результаты согласуются, как с датировкой $128 \pm 1$ млн лет (U-Pb метод по цирконам, [Стриха, 2016]) для гранитов этого же массива вне рудного поля, так и данными для гранитоидов верхнеамурского и буриндинского комплексов 140-127 млн лет [Сорокин и др., 2004б].

Более сложная ситуация отмечается для дацитов дайкового тела силлобразной формы ("силла"), что обусловлено вторичными преобразованиями пород. По нашему мнению, наиболее реальный возраст первичной породы может быть оценен по возрасту биотита из образца АМ-4 (125 \pm 2 млн лет, рис. 5в). В этом случае рассматриваемые дациты соответствуют по своему возрасту породам талданского вулканического комплекса, для которых получены датировки в интервале 127-123 млн лет [Сорокин и др., 2004б; Сотников и др., 2007а]. В тоже время существует точка зрения (в частности, [Хомич, Борискина, 2003 и др.]), согласно которой дациты силлообразного тела относятся к керакскому комплексу. Здесь следует отметить, что в результате геолосъемочных работ последнего поколения [Козырев, 2002] керакский комплекс был упразднен. Это подтверждается и упомянутыми выше геохронологическими данными, согласно которым вулканические и субвулканические образования, ранее выделявшиеся в качестве керакского комплекса, имеют возраст, аналогичный породам либо талданского, либо галькинского комплекса.

Возраст основной массы из этого же образца (АМ-4) дацитов силлообразного тела имеет более молодой возраст, а именно $122 \pm 1$ млн лет (рис. 5в). И здесь следует учитывать два обстоятельства. Во-первых, в данном образце основная масса представлена хлорит-гидрослюдистым агрегатом, являющимся собственно продуктом гидротермальных вторичных преобразований. Во-вторых, этот образец характеризуются промышленными концентрациями Au (0.8 г/T), Ag (12 г/т). Это дает нам определенные основания предполагать, что гидротермальные вторичные преобразования связаны с рудным процессом. Соответственно, возраст преобразований (пропилитизации) в первом приближении можно считать возрастом гидротермального рудного процесса.

Как было отмечено выше, аргонограмма для основной массы из другого образца пропилитизированных дацитов (обр. АМ-15) силлообразного тела не позволяет выделить плато (табл., рис. 5к). Тем не менее на ней отчетливо выражены ступени с возрастом 128 млн лет, 125 млн лет, 120 млн лет и 119 млн лет. Если рассматривать такой результат, как полученный для отдельно взятого образца, то этот результат не имеет геологического смысла. Но в совокупности с имеющимися данными эта информация может быть использована для рассуждений. Так, учитывая полученный результат $125 \pm 2$ млн лет для биотита из образца (АМ-4) того же тела, мы полагаем, что ступени 128-125 млн лет, вероятнее всего, отражают возраст первичной породы, а смежные ступени с возрастом 120 
- 119 млн лет (в совокупности 39\% выделенного ${ }^{39} \mathrm{Ar}$ ) - возраст наложенного термального процесса. При этом данный образец (АМ-15) характеризуются промышленными концентрациями $\mathrm{Au}(0.7$ г/T), $\mathrm{Ag}$ (5 г/т).

В целом, полученные геохронологические результаты указывают на то, что первичный возраст дацитов силлообразного тела может быть оценен в интервале 128-125 млн лет, что соответствует возрасту вулканических пород талданского комплекса, для которых ранее получены датировки в интервале 127-123 млн лет [Сорокин и др., 2004б, Сотников и др., 2007a].

Возраст наложенных на эти дациты процессов пропилитизации, в первом приближении, может быть оценен интервалом 122-119 млн лет. С учетом присутствия в рассматриваемых породах золота и серебра, мы имеем основания предполагать, что этот возрастной интервал может быть распространен и на процесс формирования рудных тел.

Рассматриваемый интервал 122-119 млн лет существенно моложе датировок, полученных в последние годы для вулканических и субвулканических образований талданского комплекса, и, в этой связи, связать процессы рудообразования с этим комплексом не представляется возможным. В тоже время, этот интервал соответствует возрасту формирования галькинского вулканического комплекса (119-115 млн лет), сопровождаемого гранитоидным магматизмом того же возраста [Сорокин и др., 2013]. Мы также не исключаем, что, по крайней мере, часть даек гранит-порфиров, проявленных в пределах месторождения Покровское может относиться к галькинскому комплексу.

Кроме того, полученные данные позволяют провести сравнительный анализ возрастов рудных объектов Приамурья, и, прежде всего, в пределах северной части Аргунского континентального массива. Так золото-серебряное месторождение Покровское имеет более молодой возраст, чем золото-серебряное месторождение Буринда (128-126 млн лет, ${ }^{40} \mathrm{Ar} /{ }^{39} \mathrm{Ar}$ метод) [Бучко и др., 2019], молибден-медно-порфировое с золотом месторождение Боргуликан (123-122 млн лет, ${ }^{40} \mathrm{Ar} /{ }^{39} \mathrm{Ar}$ метод) [Сотников и др., 2007a] и практически совпадает с возрастом медно-порфирового с золотом рудопроявления Елна (122-117 млн лет, ${ }^{40} \mathrm{Ar} /{ }^{39} \mathrm{Ar}$ метод) [Бучко и др., 2017].

Далее обратимся к месторождениям, расположенным в пределах юго-восточного обрамления Северо-Азиатского кратона. К ним относятся золото-полиметаллическое месторождение Березитовое ( 132-125 млн лет, ${ }^{40} \mathrm{Ar} /{ }^{39} \mathrm{Ar}$ метод, [Мельников и др., 2009; Сорокин и др., 2014а]), серебро-полиметаллическое месторождение Моготинское ( 127125 млн лет, ${ }^{40} \mathrm{Ar} /{ }^{39} \mathrm{Ar}$ метод, [Бучко и др., 2014]), золото-серебряное рудопроявление Дёсс ( 129 млн лет, ${ }^{40} \mathrm{Ar} /{ }^{39} \mathrm{Ar}$ метод, [Бучко и др., 2012]), молибден-медно-порфировое рудопроявление Выходное ( 125-122 млн лет, ${ }^{40} \mathrm{Ar} /{ }^{39} \mathrm{Ar}$ метод, [Сотников и др., 2007б]).

Приведенные данные указывают на то, месторождение Покровское отвечает наиболее молодому этапу рудообразования в пределах рассматриваемого региона.

\section{ВЫВОДЫ}

Полученные в результате проведенных исследований результаты позволяют сформулировать следующие выводы:

1) Возраст гранитов Сергеевского массива верхнеамурского комплекса, вмещающих рудные тела, составляет 129 млн лет.

2) Первичный возраст дацитов силлообразного тела, может быть оценен в интервале 128-125 млн лет, что соответствует возрасту вулканических пород талданского комплекса. 
3) Возраст наложенных на эти дациты процессов пропилитизации, в первом приближении, может быть оценен интервалом 122-119 млн лет. Принимая во внимание присутствие в рассматриваемых породах промышленных концентраций золота и серебра, мы имеем основания предполагать, что этот возрастной интервал может быть распространен и на процесс формирования рудных тел.

4) В пределах Умлеканской вулканической зоны на рассматриваемый возрастной интервал (122-119 млн лет) приходится становление галькинского вулканического комплекса, сопровождаемого гранитоидным магматизмом того же возраста. На этом основании мы полагаем, что формирование месторождения Покровское, вероятно, связано с галькинским комплексом.

\section{БЛАГОДАРНОСТИ}

Авторы выражают благодарность сотрудникам лабораторий Института геологии и природопользования ДВО РАН (О.Н. Белозеровой, В.В. Глушенковой) за подготовку препаратов для геохронологических исследований.

Исследования выполнены при поддержке Комплексной программы фундаментальных исследований ДВО РАН "Дальний Восток" (проект 18-2-015).

\section{ЛИТЕРАТУРА}

Бучко И.В., Сорокин А.А., Пономарчук В.А., Травин А.В., Бучко Ир.В. Возраст и связь с магматизмом золото-серебряного оруденения рудопроявления Десс СевероСтановой металлогенической зоны (юго-восточное обрамление Северо-Азиатского кратона) // Тихоокеан. геология, 2012, т. 31, № 2, с. 69-74.

Бучко И.В., Бучко Ир.В., Сорокин А.А., Пономарчук В.А., Травин А.В. Закономерности локализации оруденения, возраст и связь с магматизмом сереброполиметаллического месторождения Моготинское (Северо-Становая металлогеническая зона, юго-восточное обрамление Северо-Азиатского кратона) // Геология руд. месторождений, 2014, т. 56, № 2, с. 118-130.

Бучко И.В., Сорокин А.А., Пономарчук А.В., Травин А.В., Пономарчук В.А. ${ }^{40} \mathrm{Ar} /{ }^{39} \mathrm{Ar}$ возраст и связь с магматизмом медно-порфирового с золотом оруденения рудопроявления Елна (северо-восточная часть Аргунского супертеррейна) // Доклады академии наук, 2017, т. 472, № 2, с. 175-179.

Бучко И.В., Сорокин А.А., Пономарчук В.А., Травин А.В. ${ }^{40} \mathrm{Ar} /{ }^{39} \mathrm{Ar}$ возраст и связь с магматизмом золото-серебряного оруденения месторождения Буринда (северовосточная часть Аргунского супертеррейна) // Доклады академии наук, 2019, т. 485, №3. С. 321-325.

Волостных Г.Т. Аргиллизация и оруденение. М., Недра, 1972, 240 с.

Геодинамика, магматизм и металлогения востока России. Кн. 1 / Ред. А.И. Ханчук. Владивосток, Дальнаука, 2006, 572 с.

Геологическая карта Приамурья и сопредельных территорий. Масштаб 1:2500000. Объяснительная записка / Л.И. Красный, А.С. Вольский, И.А. Васильев, Пэн Юньбяо, Сюй Яньцянь, Ван Ин. С.-Петербург, ВСЕГЕИ, 1999, 135 с.

Гордиенко И.В., Метелкин Д.В., Ветлужских Л.И. Строение Монголо-Охотского складчатого пояса и проблема выделения Амурского микроконтинента // Геология и геофизика, 2019, т. 60, № 3, с. 318-341. 
Ефремов С.В., Спиридонов А.М., Травин А.В. Новые данные о возрасте, генезисе и источниках вещества гранитоидов Карийского золоторудного узла (Восточное Забайкалье) // Геология и геофизика, 2019, т. 60, № 6, с. 772-788.

Золоторудные месторождения России / ред. М.М. Константинов. М., Акварель, 2010, 349 c.

Зубков В.Ф., Вольский А.С. Геологическая карта региона БАМ. Масштаб 1: 500 000. Лист N-52-В / Ред. В.Ф. Зубков. Л., ВСЕГЕИ, 1984.

Козырев С.К. Государственная геологическая карта РФ масштаба 1:200000. Издание второе. Зейская серия. Лист N-51-XXIV. С-Пб., ВСЕГЕИ, 2002.

Котов А.Б., Сорокин А.А., Сальникова Е.Б., Сорокин А.П., Ларин А.М., Великославинский С.Д., Беляков Т.В., Анисимова И.В., Яковлева С.З. Мезозойский возраст гранитоидов Бекетского комплекса (Гонжинский блок Аргунского террейна Центрально-Азиатского складчатого пояса) // Доклады Академии наук, 2009, т. 429, № 6, с. 779-783.

Котов А.Б., Мазукабзов А.М., Сковитина Т.М., Великославинский С.Д., Сорокин А.А., Сорокин А.П. Структурная эволюция и геодинамическая позиция Гонжинского блока (Верхнее Приамурье) // Геотектоника, 2013, № 5, с. 48-60.

Мартынюк М.В., Рямов С.А., Кондратьева В.А. Объяснительная записка к схеме корреляции магматических комплексов Хабаровского края и Амурской области. Хабаровск, ПГО Дальгеология, 1990, 215 с.

Мельников А.В., Сорокин А.А., Пономарчук В.А., Травин А.В., Сорокин А.П. Золото-полиметаллическое месторождение Березитовое западной части СеленгиноСтанового супертеррейна: основные минералогические особенности, возраст и связь с магматизмом // Геология и геофизика, 2009, т. 50, № 3, с. 258-265.

Парфенов Л.М., Попеко Л.И., Томуртогоо О. Проблемы тектоники МонголоОхотского орогенного пояса // Тихоокеан. геология, 1999, т. 18, № 5, с. 24-43.

Пересторонин А.Е., Степанов В.А. Вулканогенные золото-серебряные месторождения Приамурья // Металлогения, 2016, № 66, с. 113-125.

Петрук Н.Н., Козлов С.А. Государственная геологическая карта Российской Федерации масштаба 1:1000000. Лист N-51 (Сковородино). Третье поколение. Дальневосточная серия / Ред. А.С. Вольский. СПб., ВСЕГЕИ, 2009.

Пономарчук В.А., Лебедев Ю.Н., Травин А.В., Морозова И.П., Киселева В.Ю., Титов А.Т. Применение тонкой магнитно-сепарационной технологии в $\mathrm{K}-\mathrm{Ar},{ }^{40} \mathrm{Ar}-{ }^{39} \mathrm{Ar}$, $\mathrm{Rb}-\mathrm{Sr}$ методах датирования пород и минералов // Геология и геофизика, 1998, т. 39 (1), c. 55-64.

Решения IV межведомственного регионального стратиграфического совещания по докембрию и фанерозою юга Дальнего Востока и Восточного Забайкалья. Комплект схем. Хабаровск, ХГГГП, 1994.

Сальникова Е.Б., Котов А.Б., Ковач В.П., Великославинский С.Д., Джан Б.-М., Сорокин А.А., Сорокин А.П., Ван К.-Л., Чан С.-Л., Толмачева Е.В. О возрасте гонжинской серии (Аргунский террейн Центрально-Азиатского складчатого пояса): результаты U-Pb и Lu-Hf изотопных исследований детритовых цирконов // Доклады Академии наук, 2012, т. 444, № 5, с. 519-522.

Сережников А.Н., Волкова, Ю.P. Государственная геологическая карта Российской Федерации. Масштаб 1:1 000 000. Третье поколение. Лист N-52 (Зея). С.Петербург, ВСЕГЕИ, 2005. 
Сорокин А.А., Кудряшов Н.М., Ли Цзиньи, Журавлев Д.З., Ян Пин, Сун Гуйхуа, Гао Лиминг. Раннепалеозойские гранитоиды восточной окраины Аргунского террейна (Приамурье): первые геохронологические и геохимические данные // Петрология, 2004a, т. 12, № 4, с. 414-424.

Сорокин А.А., Пономарчук В.А., Сорокин А.П., Козырев С.К. Геохронология и корреляция мезозойских магматических образований северной окраины Амурского супертеррейна // Стратиграфия. Геологическая корреляция, 2004б, т. 12, № 6, с. 38-54.

Сорокин А.А., Котов А.Б., Кудряшов Н.М., Ковач В.П. Позднепалеозойский урушинский магматический комплекс южного обрамления Монголо-Охотского пояса (Приамурье): возраст и геодинамическая позиция // Петрология, 2005, т. 13, № 6, c. 654-670.

Сорокин А.А., Сорокин А.П., Пономарчук В.А., Травин А.В., Мельникова О.В. Позднемезозойский вулканизм восточной части Аргунского супертеррейна (Дальний восток): ${ }^{40} \mathrm{Ar} /{ }^{39} \mathrm{Ar}$ геохронологические и геохимические данные // Стратиграфия, Геологическая корреляция, 2009, т. 17, № 6, с. 90-104.

Сорокин А.А., Сорокин А.П., Пономарчук В.А., Травин А.В. Возраст и геохимические особенности вулканических пород восточного фланга УмлеканоОгоджинского вулкано-плутонического пояса (Приамурье) // Геология и геофизика, 2010, т. 51, № 4, с. 473-485.

Сорокин А.А., Котов А.Б., Пономарчук В.А., Сорокин А.П., Ковач В.П., Саватенков В.М. Аптские бимодальные вулканические ассоциации и гранитоиды северной окраины Амурского микроконтинента: возраст, источники и геодинамическая обстановка формирования // Петрология, 2013, т. 21, № 1, с. 74-93.

Сорокин А.А., Пономарчук В.А., Травин А.В., Рогулина Л.И., Пономарчук А.В. Корреляция процессов рудообразования на золото-полиметаллическом месторождении Березитовое западной части Селенгино-Станового супертеррейна и региональных тектоно-магматических событий // Геология и геофизика, 2014а, т. 55, № 3, с. 432-448.

Сорокин А.А, Смирнов Ю.В., Котов А.Б., Сальникова Е.Б., Сорокин А.П., Ковач В.П., Яковлева С.З., Анисимова И.В. Раннепалеозойский возраст исагачинской толщи чаловской серии Гонжинского террейна (восточная часть Центрально-Азиатского складчатого пояса) // Доклады Академии наук, 2014б, т. 457, № 3, с. 323-326.

Сотников В.И., Пономарчук В.А., Сорокин А.А., Сорокин А.П., Гимон В.О Возрастные рубежи формирования Cu-Mo-порфировых месторождений в структурах обрамления Монголо-Охотского орогенного пояса. // Доклады Академии наук, 2005, т. 403, № 4, с. 522-525.

Сотников В.И., Сорокин А.А., Пономарчук В.А., Гимон В.О., Сорокин А.П. Возраст Мo-Cu-(Au)-порфирового оруденения и магматических комплексов Боргуликанского рудного поля (Верхнее Приамурье) // Геология и геофизика, 2007а, т. 48, № 2, с. 229-237.

Сотников В.И., Сорокин А.А., Пономарчук В.А., Травин А.В., Сорокин А.П., Гимон В.О. Геохронология мезозойских гранитоидов и связанного с ними молибденового оруденения западной части Джугджуро-Станового супертеррейна // Доклады Академии наук, 2007б, т. 416, № 6, с. 794-798.

Стриха B.E. U-Pb изотопный возраст (SHRIMP-II) гранитоидов магдагачинского комплекса Умлекано-Огоджинской вулкано-плутонической зоны // Вестник АмГУ, 2016, Выпуск 75, с. 73-79. 
Травин А.В., Юдин Д.С., Хромых С.В., Волкова Н.И., Мехоношин А.С., Владимиров А.Г., КолотилинаТ.Б. Термохронология Чернорудской гранулитовой зоны (Ольхонский регион, Западное Прибайкалье) // Геохимия, 2009, т. 11, с. 1181-1199.

Хомич В.Г., Борискина Н.Г. Инъективные структуры и золото-серебряное оруденение Покровского рудного поля (Приамурье) // Геология руд. месторождений, 2003, т. 45, № 1, с. 25-38.

Хомич В.Г., Борискина Н.Г. Геологическая позиция благороднометалльных месторождений интрузивно-вулканогенного обрамления Гонжинского выступа докембрия (Верхнее Приамурье) // Тихоокеан. геология, 2006, т. 25, № 3, с. 53-65.

Эйриш Л.В. Металлогения золота Приамурья (Амурская область, Россия). Владивосток, Дальнаука, 2002, 194 с.

Baksi A.K., Archibald D.A., Farrar E. Intercalibration of ${ }^{40} \mathrm{Ar} /{ }^{39} \mathrm{Ar}$ dating standards // Chemical Geology, 1996, v. 129, p. 307-324.

Berger B.W., York D. Geothermometry from ${ }^{40} \mathrm{Ar} /{ }^{39} \mathrm{Ar}$ dating experements // Geochim. et Cosmochim. Acta, 1981, v. 45, № 6, p. 795-811.

Fleck R.J., Sutter J.F., Elliot D.H. Interpretation of discordant ${ }^{40} \mathrm{Ar} /{ }^{39} \mathrm{Ar}$ age spectra of Mesozoic tholeites from Antarctica // Geochim. Cosmochim. Acta, 1977, v. 41, № 1, p. 15-32.

Gustafson L.B., Orquera W., McWilliams M., Castro M., Olivares O., Rojas G., Maluenda J., Mendez M. Multiple centers of mineralization in the Indio Muerto District, El Salvador, Chile // Econ. Geol., 2001, v. 96, № 2, p. 325-350.

Ludwig K.R. Isoplot/EX version 3.0. A geochronological toolkit for Microsoft Excel: Berkeley Geochronology Center Special Publication, 2003.

Miao L., Zhang F., Zhu M., Liu D. Zircon SHRIMP U-Pb dating of metamorphic complexes in the conjunction of the Greater and Lesser Xing'an ranges, NE China: Timing of formation and metamorphism and tectonic implications // Journal of Asian Earth Sciences, 2015, v. 114, p. 634-648.

Wu F.Y., Sun D.Y., Ge W.C., Zhang Y.B., Grant M.L., Wilde S.A., Jahn B.M. Geochronology of the phanerozoic granitoids in northeastern China // Journal of Asian Earth Sciences, 2011, v. 41, p. 1-30.

Wu G., Chen Y.C., Chen Y.J., Zeng Q.T. Zircon U-Pb ages of the metamorphic supracrustal rocks of the Xinghuadukou Group and granitic complexes in the Argun massif of the northern Great Hinggan Range, NE China, and their tectonic implications // Journal of Asian Earth Sciences, 2012, v. 49, p. 214-233. 


\section{Подрисуночные подписи}

Рис. 1. Геологическая схема северо-восточной окраины Аргунского континентального массива. Составлена по [Зубков, Вольский, 1984] с упрощениями.

1 - голоценовые рыхлые отложения; 2 - неогеновые и до-голоценовые четвертичные рыхлые отложения; 3 - нижнемеловые базальты, риолиты, туфы, туфобрекчии, туфопесчаники галькинской свиты; 4 - нижнемеловые андезиты, дациты их туфы, кластолавы, субвулкадические диоритовые порфириты талданской свиты; 5 - раннемеловые граниты, гранодиориты верхнеамурского и буриндинского комплексов; 6 - нижнемеловые песчаники, конгломераты, алевролиты перемыкинской свиты; 7 - верхнеюрские песчаники, алевролиты, аргиллиты осежинской свиты; 8 - позднепалеозойские кварцевые диориты, гранодиориты урушинского комплекса; 9 - девонские и нижнекаменноугольные песчаники, алевролиты с пластами известняков большеневерской, имачинской, ольдойской, типаринской свит; 10 условно раннепалеозойские граниты, гранодиориты, кварцевые диориты; 11 - условно позднепротерозойские метаморфические комплексы; 12 - главные разломы; 13 - контур Улунгинского медно-серебро-золоторудного узла.

На врезке приведена схема расположения мезозойских вулканических и вулканоплутонических поясов (ареалов) восточной окраины Азиатского континента по [Геологическая..., 1999]. 1 - Монголо-Забайкальский вулканический пояс $\left(\mathrm{J}_{2-3}-\mathrm{K}_{1}\right) ; 2$ Большехинганский вулканоплутонический пояс $\left(\mathrm{J}_{3}-\mathrm{K}_{1}\right) ; 3-$ Умлекано-Огоджинский вулканоплутонический пояс $\left(\mathrm{K}_{1}-\mathrm{K}_{2}\right) ; 4$ - Хингано-Охотский вулканоплутонический пояс $\left(\mathrm{K}_{1}-\right.$ $\left.\mathrm{K}_{2}\right) ; 5$ - Охотско-Чукотский вулканоплутонический пояс $\left(\mathrm{K}_{1}-\mathrm{K}_{2}\right) ; 6$ - Восточно-СихотэАлинский вулканоплутонический пояс $\left(\mathrm{K}_{1}-\mathrm{K}_{2}\right) ; 7$ - Становой плутонический пояс $\left(\mathrm{K}_{1}-\mathrm{K}_{2}\right) ; 8$ - Монголо-Охотский складчатый пояс; 9 - район исследований.

Рис. 2. Позиция рудных месторождений северо-восточной окраины Аргунского континентального массива.

Рис. 3. Схематическая геологическая карта месторождения Покровское. Составлена по [Пересторонин, Степанов, 2016] с упрощениями авторов.

1 - голоценовые рыхлые отложения; 2 - неогеновые и до-голоценовые четвертичные рыхлые отложения; 3 - нижнемеловые базальты, риолиты, туфы, туфобрекчии, туфопесчаники галькинской свиты; 4 - субвулканические и дайковые тела дацитов; 5 - нижнемеловые андезиты, дациты их туфы, кластолавы, субвулкадические диоритовые порфириты талданской свиты; 6 - дайковые тела гранит-порфиров; 7 - раннемеловые граниты, 
гранодиориты верхнеамурского и буриндинского комплексов; 8 - верхнеюрские песчаники, алевролиты, аргиллиты осежинской; 9 - главные разломы; 10 - ареалы развития кварцсерицит-гидрослюдистых метасоматитов; 11 - кварцевые тела (жилы); 12 - проекции рудных тел; 13 - места отбора образцов для геохронологических исследований и их номера.

Рис. 4. Схематический геологический разрез месторождения Покровское по линии А-Б, показанной на рисунке 3. Составлен по [Золоторудные..., 2010; Пересторонин, Степанов, 2016] с упрощениями авторов.

Подрисуночные подписи на рис.3

Рис. 5. Графики ступенчатого прогрева и изохроны для минеральных фракций из магматических и гидротермально-измененных пород месторождения Покровское. Номера образцов соответствуют номерам в тексте, таблице. СКВО для плато рассчитано по программе ISOPLOT 3 [Ludwig, 2003]. Возраст приведен с погрешностью $\pm 2 \sigma$. 
Таблица. Результаты ${ }^{40} \mathrm{Ar} /{ }^{39} \mathrm{Ar}$ датирования минеральных фракций из магматических и гидротермально-измененных пород Покровское методом ступенчатого прогрева

\begin{tabular}{|c|c|c|c|c|c|c|}
\hline $\begin{array}{c}\text { № } \\
\text { ступени }\end{array}$ & $\mathrm{T}^{\circ} \mathrm{C}$ & ${ }^{39} \mathrm{Ar}, \%$ & ${ }^{40} \mathrm{Ar} /{ }^{39} \mathrm{Ar}( \pm 1 \sigma)$ & ${ }^{37} \mathrm{Ar} /{ }^{39} \mathrm{Ar}( \pm 1 \sigma)$ & ${ }^{36} \mathrm{Ar} /{ }^{39} \mathrm{Ar}( \pm 1 \sigma)$ & $\begin{array}{c}\text { Возраст, } \\
\text { млн. лет. }( \pm 1 \sigma)\end{array}$ \\
\hline \multicolumn{7}{|c|}{ Образец АM-3, полевой шпат, J=0.003913 \pm 0.00004} \\
\hline 1 & 550 & 2.2 & $64.805 \pm 1.907$ & $52.896 \pm 30.168$ & $0.134 \pm 0.018$ & $169.6 \pm 34.6$ \\
\hline 2 & 670 & 9.5 & $37.830 \pm 0.500$ & $54.721 \pm 14.766$ & $0.031 \pm 0.007$ & $191.7 \pm 13.0$ \\
\hline 3 & 790 & 28.3 & $29.148 \pm 0.194$ & $12.700 \pm 4.992$ & $0.037 \pm 0.005$ & $123.8 \pm 10.7$ \\
\hline 4 & 900 & 52.4 & $22.801 \pm 0.193$ & $3.091 \pm 9.363$ & $0.020 \pm 0.004$ & $115.4 \pm 8.7$ \\
\hline 5 & 1000 & 72.1 & $22.949 \pm 0.146$ & $26.858 \pm 6.841$ & $0.014 \pm 0.004$ & $128.9 \pm 7.0$ \\
\hline 6 & 1130 & 100.0 & $22.392 \pm 0.064$ & $4.923 \pm 3.040$ & $0.013 \pm 0.002$ & $126.7 \pm 3.3$ \\
\hline \multicolumn{7}{|c|}{ Образец, АМ-4, биотит, J=0.003906 \pm 0.00004} \\
\hline 1 & 500 & 1.5 & $44.44 \pm 0.97$ & $40.46 \pm 35.44$ & $0.0452 \pm 0.0149$ & $206.7 \pm 28.0$ \\
\hline 2 & 600 & 5.8 & $28.74 \pm 0.24$ & $1.00 \pm 1.00$ & $0.0271 \pm 0.0027$ & $140.6 \pm 5.5$ \\
\hline 3 & 700 & 12.8 & $24.17 \pm 0.09$ & $1.00 \pm 1.00$ & $0.0173 \pm 0.0037$ & $129.5 \pm 7.3$ \\
\hline 4 & 800 & 29.6 & $23.03 \pm 0.13$ & $1.00 \pm 1.00$ & $0.0179 \pm 0.0010$ & $120.8 \pm 2.4$ \\
\hline 5 & 900 & 37.0 & $23.15 \pm 0.12$ & $1.00 \pm 1.00$ & $0.0130 \pm 0.0030$ & $131.2 \pm 5.9$ \\
\hline 6 & 1000 & 66.5 & $20.48 \pm 0.04$ & $1.00 \pm 1.00$ & $0.0068 \pm 0.0008$ & $125.7 \pm 2.0$ \\
\hline 7 & 1130 & 100.0 & $20.50 \pm 0.02$ & $1.00 \pm 1.00$ & $0.0055 \pm 0.0013$ & $128.3 \pm 2.9$ \\
\hline \multicolumn{7}{|c|}{ 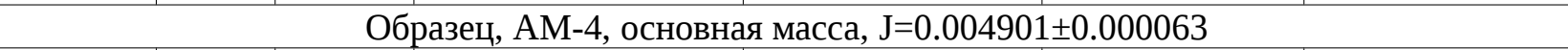 } \\
\hline 1 & 500 & 2.1 & $37.73 \pm 1.77$ & $74.03 \pm 52.27$ & $0.0279 \pm 0.0240$ & $195.0 \pm 45.3$ \\
\hline 2 & 620 & 9.3 & $22.37 \pm 0.15$ & $5.77 \pm 4.60$ & $0.0094 \pm 0.0055$ & $131.9 \pm 10.7$ \\
\hline 3 & 720 & 29.9 & $19.98 \pm 0.04$ & $3.20 \pm 1.65$ & $0.0044 \pm 0.0012$ & $125.9 \pm 2.7$ \\
\hline 4 & 820 & 61.3 & $18.63 \pm 0.01$ & $2.23 \pm 0.70$ & $0.0029 \pm 0.0004$ & $120.1 \pm 1.4$ \\
\hline 5 & 920 & 83.1 & $18.43 \pm 0.02$ & $3.63 \pm 0.98$ & $0.0006 \pm 0.0006$ & $123.2 \pm 1.7$ \\
\hline 6 & 1020 & 92.3 & $19.08 \pm 0.09$ & $13.13 \pm 4.84$ & $0.0010 \pm 0.0010$ & $129.5 \pm 4.9$ \\
\hline 7 & 1130 & 100.0 & $17.99 \pm 0.06$ & $8.48 \pm 3.61$ & $0.0063 \pm 0.0020$ & $109.3 \pm 4.0$ \\
\hline \multicolumn{7}{|c|}{ Образец, АМ-13, биотит, $\mathrm{J}=0.003882 \pm 0.000039$} \\
\hline 1 & 650 & 4.0 & $55.42 \pm 1.25$ & $0.010 \pm 0.010$ & $0.118 \pm 0.011$ & $137.8 \pm 19.7$ \\
\hline 2 & 800 & 19.6 & $26.60 \pm 0.04$ & $0.010 \pm 0.005$ & $0.026 \pm 0.003$ & $128.2 \pm 6.0$ \\
\hline 3 & 915 & 55.9 & $21.53 \pm 0.07$ & $0.009 \pm 0.003$ & $0.011 \pm 0.002$ & $122.8 \pm 4.8$ \\
\hline 4 & 1020 & 74.8 & $23.92 \pm 0.07$ & $0.010 \pm 0.004$ & $0.021 \pm 0.003$ & $120.2 \pm 6.4$ \\
\hline 5 & 1130 & 100.0 & $22.80 \pm 0.15$ & $0.011 \pm 0.004$ & $0.020 \pm 0.005$ & $115.2 \pm 9.4$ \\
\hline \multicolumn{7}{|c|}{ Образец АМ-13, полевой шпат, J=0.00386 \pm 0.000039} \\
\hline 1 & 500 & 0.8 & $391.40 \pm 140.31$ & $1330.78 \pm 603.02$ & $0.352 \pm 0.252$ & $1346.4 \pm 401.3$ \\
\hline 2 & 600 & 5.2 & $78.00 \pm 4.91$ & $221.72 \pm 68.79$ & $0.058 \pm 0.036$ & $380.7 \pm 63.0$ \\
\hline 3 & 720 & 20.1 & $34.38 \pm 0.63$ & $23.47 \pm 20.26$ & $0.045 \pm 0.010$ & $140.8 \pm 18.4$ \\
\hline 4 & 830 & 33.8 & $29.04 \pm 0.97$ & $48.94 \pm 36.88$ & $0.017 \pm 0.018$ & $159.2 \pm 33.8$ \\
\hline 5 & 980 & 68.7 & $22.35 \pm 0.14$ & $11.92 \pm 5.53$ & $0.012 \pm 0.005$ & $126.8 \pm 9.4$ \\
\hline 6 & 1130 & 100.0 & $22.79 \pm 0.19$ & $17.72 \pm 9.12$ & $0.011 \pm 0.004$ & $130.9 \pm 8.4$ \\
\hline \multicolumn{7}{|c|}{ Образец АМ-15, основная масса, J= 0.0038 \pm 0.000038} \\
\hline 1 & 500 & 2.5 & $25.89 \pm 0.46$ & $22.96 \pm 17.40$ & $0.0345 \pm 0.0115$ & $104.5 \pm 22.1$ \\
\hline 2 & 600 & 7.5 & $21.92 \pm 0.10$ & $2.04 \pm 2.04$ & $0.0159 \pm 0.0042$ & $114.5 \pm 8.0$ \\
\hline 3 & 700 & 25.6 & $20.67 \pm 0.03$ & $5.31 \pm 1.42$ & $0.0043 \pm 0.0008$ & $128.4 \pm 1.9$ \\
\hline 4 & 780 & 52.0 & $19.12 \pm 0.03$ & $3.00 \pm 1.83$ & $0.0008 \pm 0.0009$ & $125.0 \pm 2.2$ \\
\hline 5 & 880 & 78.5 & $18.54 \pm 0.01$ & $0.39 \pm 0.39$ & $0.0014 \pm 0.0003$ & $120.2 \pm 1.3$ \\
\hline 6 & 980 & 90.9 & $18.39 \pm 0.02$ & $0.83 \pm 0.83$ & $0.0017 \pm 0.0006$ & $118.7 \pm 1.6$ \\
\hline 7 & 1050 & 94.1 & $19.90 \pm 0.07$ & $3.22 \pm 3.23$ & $0.0114 \pm 0.0021$ & $110.0 \pm 4.2$ \\
\hline 8 & 1140 & 100.0 & $16.49 \pm 0.05$ & $8.94 \pm 2.56$ & $0.0020 \pm 0.0021$ & $108.9 \pm 4.2$ \\
\hline
\end{tabular}

Примечание. $\mathrm{T}$ - температура. J - «джей-фактор»; параметр, характеризующий нейтронный поток. 


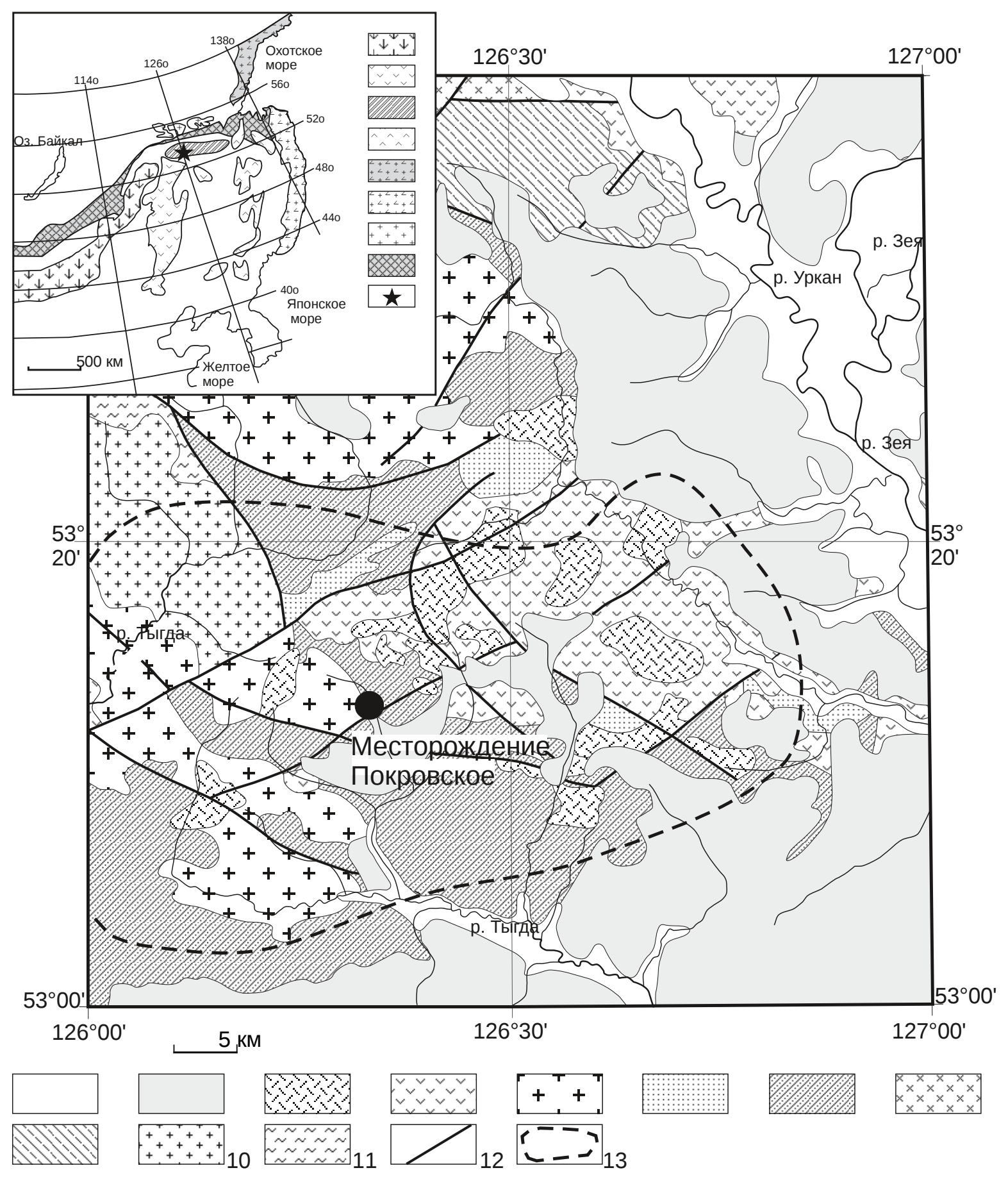

Рис. 1. 


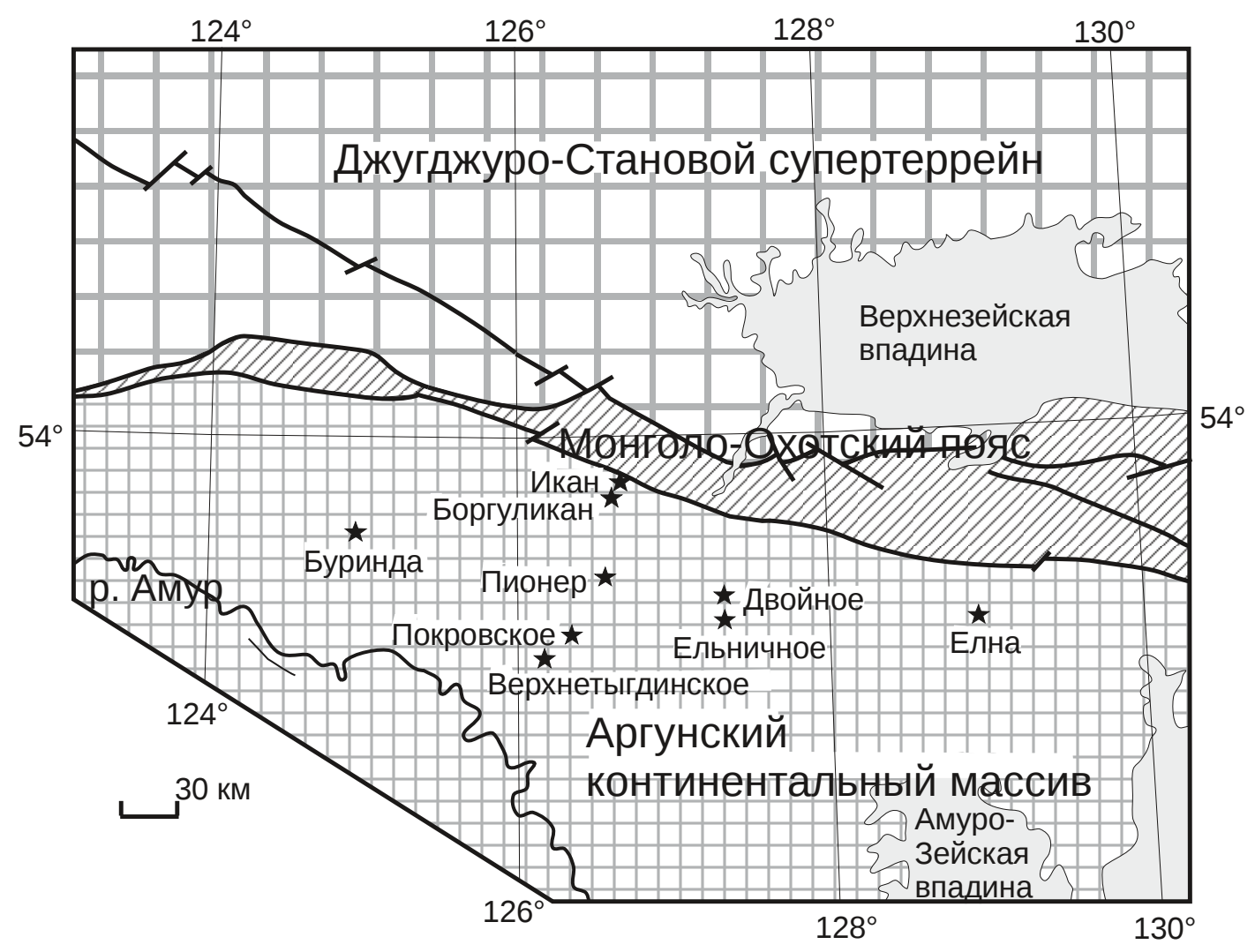

Рис. 2 


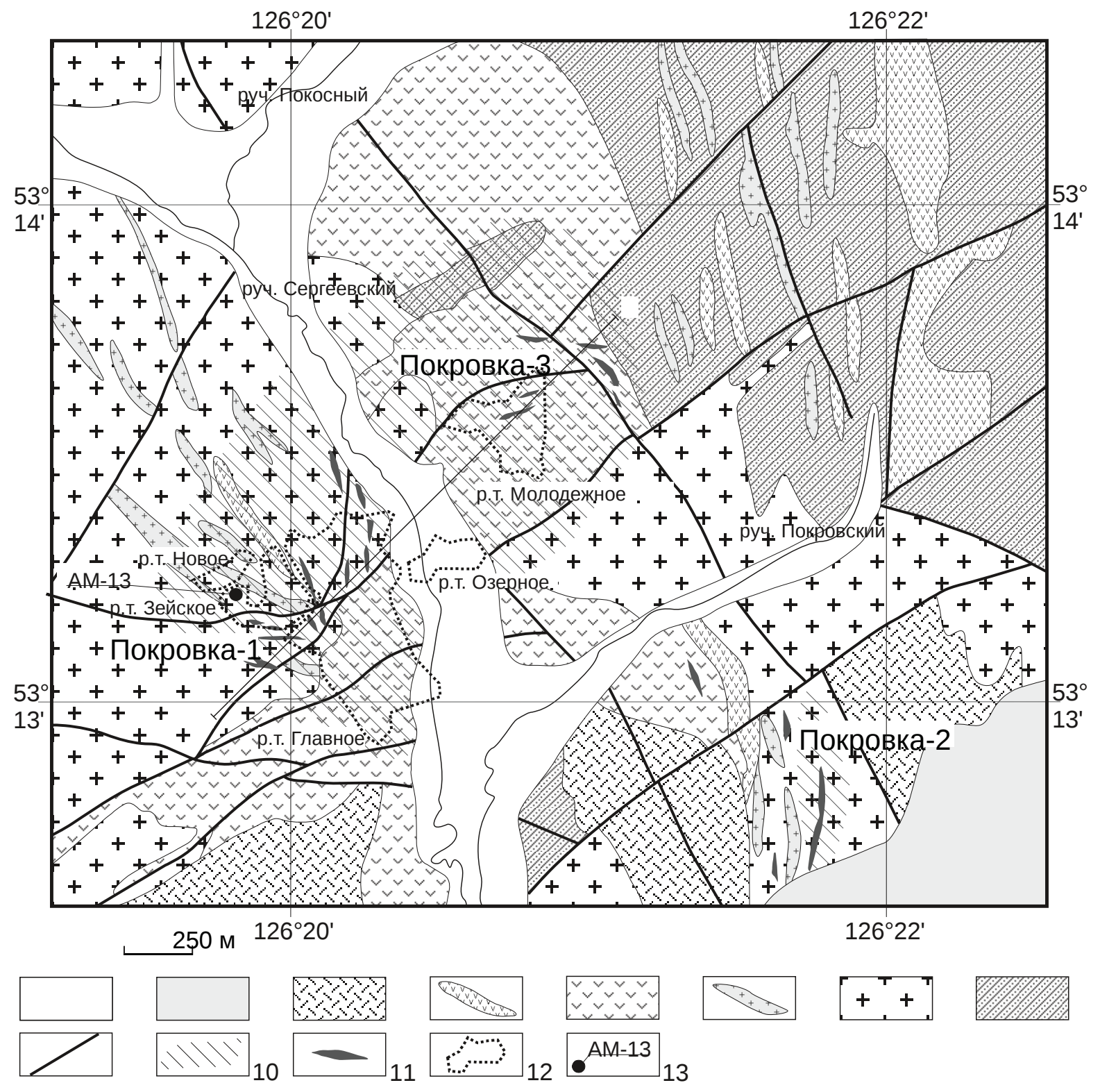

Рис. 3. 


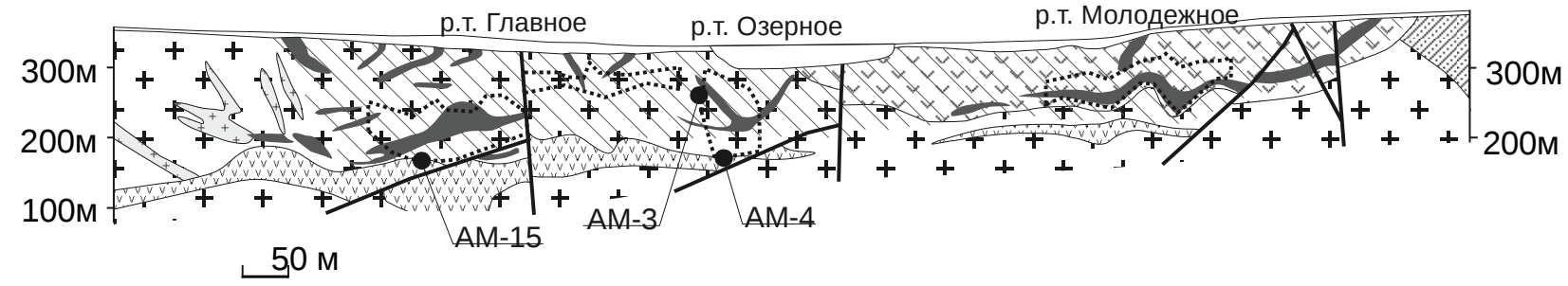

Рис. 4. 

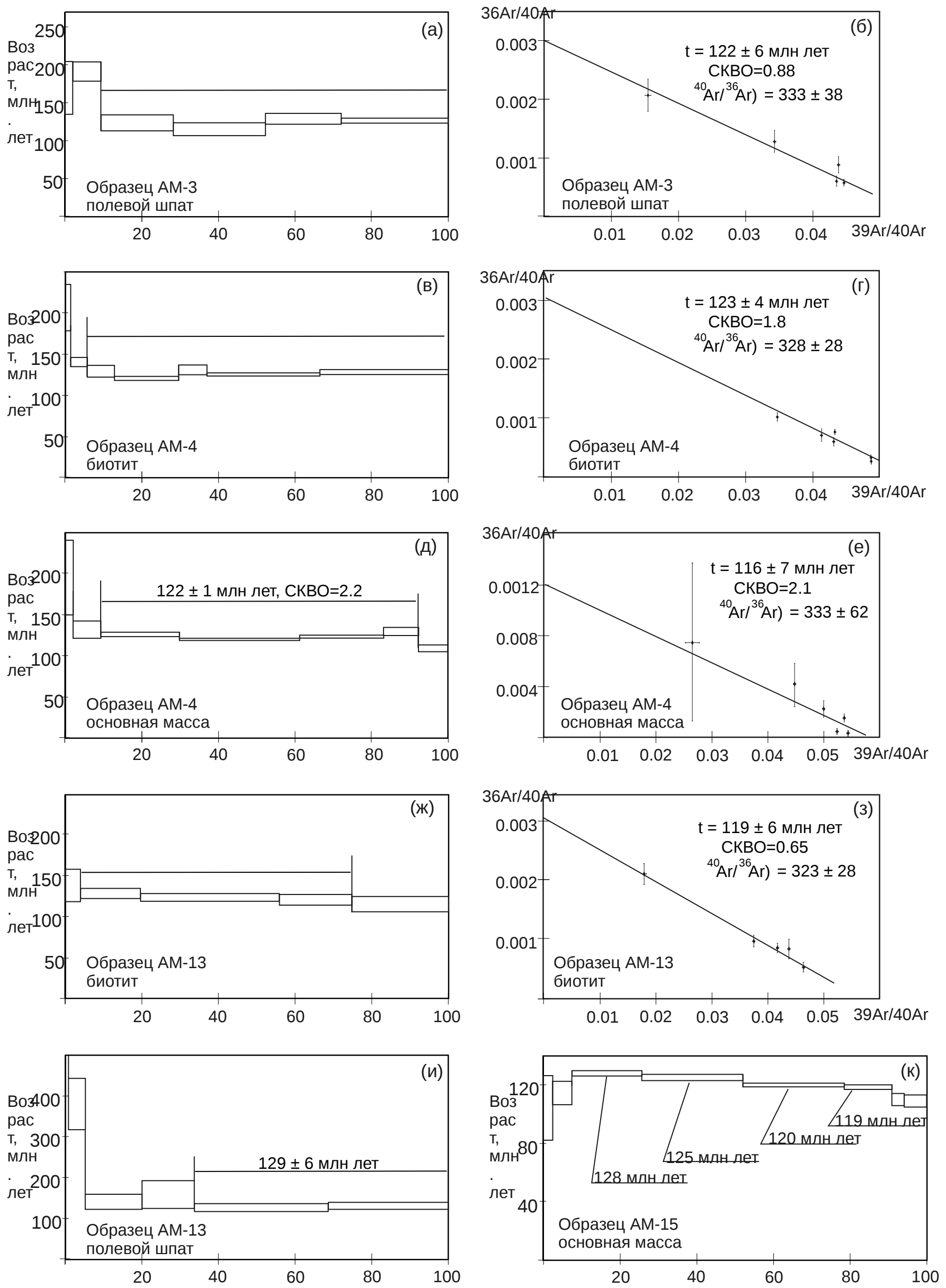

Рис. 5. 